\title{
Evaluation of the Inhibitory Activities of Ferula gummosa Bioactive Compounds against the Druggable Targets of SARS-CoV-2: Molecular Docking Simulation
}

\author{
Sepideh Habibzadeh 1,*(i), Mohammad Ebrahim Zohalinezhad ${ }^{2}$ (D) \\ Department of Chemistry, Payame Noor University, P.O. BOX 19395-3697 Tehran, Iran \\ Department of Persian Medicine, School of Medicine, Shiraz University of Medical Sciences, Shiraz, Iran \\ * Correspondence: habibzade@pnu.ac.ir (S.H.);
}

Scopus Author ID 8224029300

Received: 21.08.2021; Revised: 19.10.2021; Accepted: 22.10.2021; Published: 18.11.2021

\begin{abstract}
SARS-CoV-2, an infectious disease caused by a novel strain that belongs to a large family of coronaviruses, has emerged as a global health threat. This viral disease affects the epithelial cells of the respiratory system and eventually leads to pneumonia. Using medicine derived from natural and safe herbs could be an alternative way of preventing or even treating severe respiratory disorders. This research has been conducted to evaluate the anti-inflammatory potential of Ferula gummosa Boiss. in preventing Covid-19. Molecular docking simulation was performed on the 18 components of Ferula gummosa against known active binding sites of SARS-CoV-2. The results revealed that these compounds inhibited the vital proteins of SARS-CoV-2, including 6LU7, 6EX1, 6W9C, and 6M71. According to the docking scores (DS) and inhibition constants (Ki), the most potent anti-coronavirus activity is expressed in the order: $\Delta$-Cadinen $>\beta$-eudesmol $>$ Bulnesol. The docking results revealed that the natural components of Ferula gummosa, mainly $\Delta$-Cadinene, could be considered a valuable resource for preventing the infection of SARS-CoV-2.
\end{abstract}

Keywords: SARS-CoV-2; 6LU7; 6XE1; 6W9C; 6M71; Ferula gummosa; essential oil; molecular docking; Persian medicine.

(C) 2021 by the authors. This article is an open-access article distributed under the terms and conditions of the Creative Commons Attribution (CC BY) license (https://creativecommons.org/licenses/by/4.0/).

\section{Introduction}

In the last months of 2019, a new acute respiratory disease caused by a new coronavirus, COVID-19, was detected, and in March 2020, it was considered a pandemic by WHO [1]. This single positive-stranded RNA virus, which is novel in the coronaviruses family [2], caused worldwide deaths [3]. Several binding sites on the SARS-CoV-2 reported in the literature might be the potential druggable targets. Chymotrypsin-like protease (3CLpro), also called the main protease, is responsible for proteolytic function in the viral maturation step. Hence, it is the most important drug target for SARS-CoV-2 [4]. Another important enzyme is a papain-like protease (PLpro) which performs a crucial role in the viral replication cycle [5]. RNAdependent RNA polymerase ( $\mathrm{RdRp}$ ) plays an indispensable role in replicating and transcribing the virus [6]. The spike RBD protein attaches to the angiotensin-converting enzyme 2 (ACE2) receptor on the host cells and initiates the infection. Thus, the inhibition of the RBD-ACE2 complex is a promising strategy for the prophylaxis of COVID-19 [7]. Other binding sites of SARS-CoV-2 and their inhibitors have also been reported in the literature [8,9]. Since there are no specific therapeutic agents for COVID-19, many reviews related to herbal medicine have 
been delivered to prevent and treat this disease [10,11]. The clinical evidence of herbal medicine in treating SARS-CoV-2 infection has illustrated significant outcomes and reinforced beneficial herbal medicine for treating and preventing epidemic diseases [12].

Ferula gummosa (Apiaceae family) is one of the oldest traditional herbal medicines native to Iran, Turkey, the middle east, and southern Russia [13,14]. This plant was known in Persian medicine as Barijeh and in the Unani medicine named Gaosheer or Jawaasheer [13,15]. Avicenna (Ibn-e-Sīnā), a Persian physician (980 - June 1037 AD), recommended using its extract for the treatment of chronic cough [16,17]. Although in Persian medicine, the extract of Ferula gummosa is mainly used for gastrointestinal problems, asthma, bronchitis, and other inflammatory conditions, recent studies illustrate antimicrobial, Immunomodulatory, and antiviral therapeutic properties of Ferula gummosa [18-20].

It is essential to know the interaction between the receptors and the ligands in an initial in-silico approach in the drug discovery process. Due to the pandemic's urgent nature, many researchers performed molecular docking studies on different essential oil components against diverse receptors of SARS-CoV-2 [6, 21-24].

In this work, we analyzed the interactions of bioactive compounds from Ferula gummosa with four major binding sites of SARS-CoV-2. Molecular docking simulation was utilized to evaluate the essential parameters in protein docking; docking score energy (DS), root-mean-square deviation (RMSD), type of interactions, and the distances. Also, the druglikeliness of the compounds is discussed. Based on the inhibitory results obtained from the major components of Ferula gummosa against COVID-19's receptors, we suggest that using this medicinal herb may be appropriate for preventing SARS-CoV-2 and limiting its inflammation.

\section{Materials and Methods}

\subsection{Ligand selection and preparation.}

Essential oil components of Ferula species were investigated and reported based on GC/MS analysis [25]. Eighteen compounds having antiviral and antimicrobial properties were selected among them. The 3-Dimensional structures of the ligands, listed in Table 1, were obtained and saved from PubChem in .sdf format (PubChem URL:https://pubchem.ncbi.nlm.nih.gov/). Each ligand was optimized with $\mathrm{MM}^{+}$and AM1 minimization methods continuously, using HyperChem 8. The Gasteiger-Marsili procedure was conducted to calculate the atom's partial charges using AutoDock Tools [26]. At the final step, rotatable bonds of the compounds were assigned, and non-polar hydrogens were merged. The output structures were converted to .pdbqt format using MGLtools 1.5.6 [27].

\subsection{Receptor preparation.}

The 3-Dimensional protein structures of the known receptors were downloaded from PDB (Protein Data Bank URL:-www.rcsb.org) as .pdb files. The PDB IDs of 3CLpro, Spike RBD, PLpro, and RdRp proteins were 6LU7, 6XE1, 6W9C, 6M71, respectively. Using AutoDock Tools, all water molecules were removed, non-polar hydrogens were merged, missing hydrogens were added, and Kollman united atom charges were calculated [28]. At the final step of the process, desolvation parameters were assigned to the atoms. These minimized 
protein structures were saved as .pdb files, which eventually converted to .pdbqt files for the docking procedure.

Table 1. Identification of the bioactive compounds in Ferula gummosa.

\begin{tabular}{|c|c|c|c|c|}
\hline No. & Compound & Formula & PubChem ID & Chemical Structure \\
\hline 1 & $\alpha$-Cadinol & $\mathrm{C}_{15} \mathrm{H}_{26} \mathrm{O}$ & 6431302 & \\
\hline 2 & $\alpha$-Pinene & $\mathrm{C}_{10} \mathrm{H}_{16}$ & 6654 & \\
\hline 3 & $\beta$-Eudesmol & $\mathrm{C}_{15} \mathrm{H}_{26} \mathrm{O}$ & 91457 & \\
\hline 4 & $\beta$-Pinene & $\mathrm{C}_{10} \mathrm{H}_{16}$ & 14896 & \\
\hline 5 & Borneol & $\mathrm{C}_{10} \mathrm{H}_{18} \mathrm{O}$ & 64685 & \\
\hline 6 & Bulnesol & $\mathrm{C}_{15} \mathrm{H}_{26} \mathrm{O}$ & 90785 & \\
\hline 7 & Camphene & $\mathrm{C}_{10} \mathrm{H}_{16}$ & 6616 & \\
\hline 8 & cis-Osimene & $\mathrm{C}_{10} \mathrm{H}_{16}$ & 5320250 & \\
\hline 9 & $\Delta$-Cadinene & $\mathrm{C}_{15} \mathrm{H}_{24}$ & 441005 & \\
\hline 10 & $\gamma$-Cadinene & $\mathrm{C}_{15} \mathrm{H}_{24}$ & 6432404 & \\
\hline
\end{tabular}




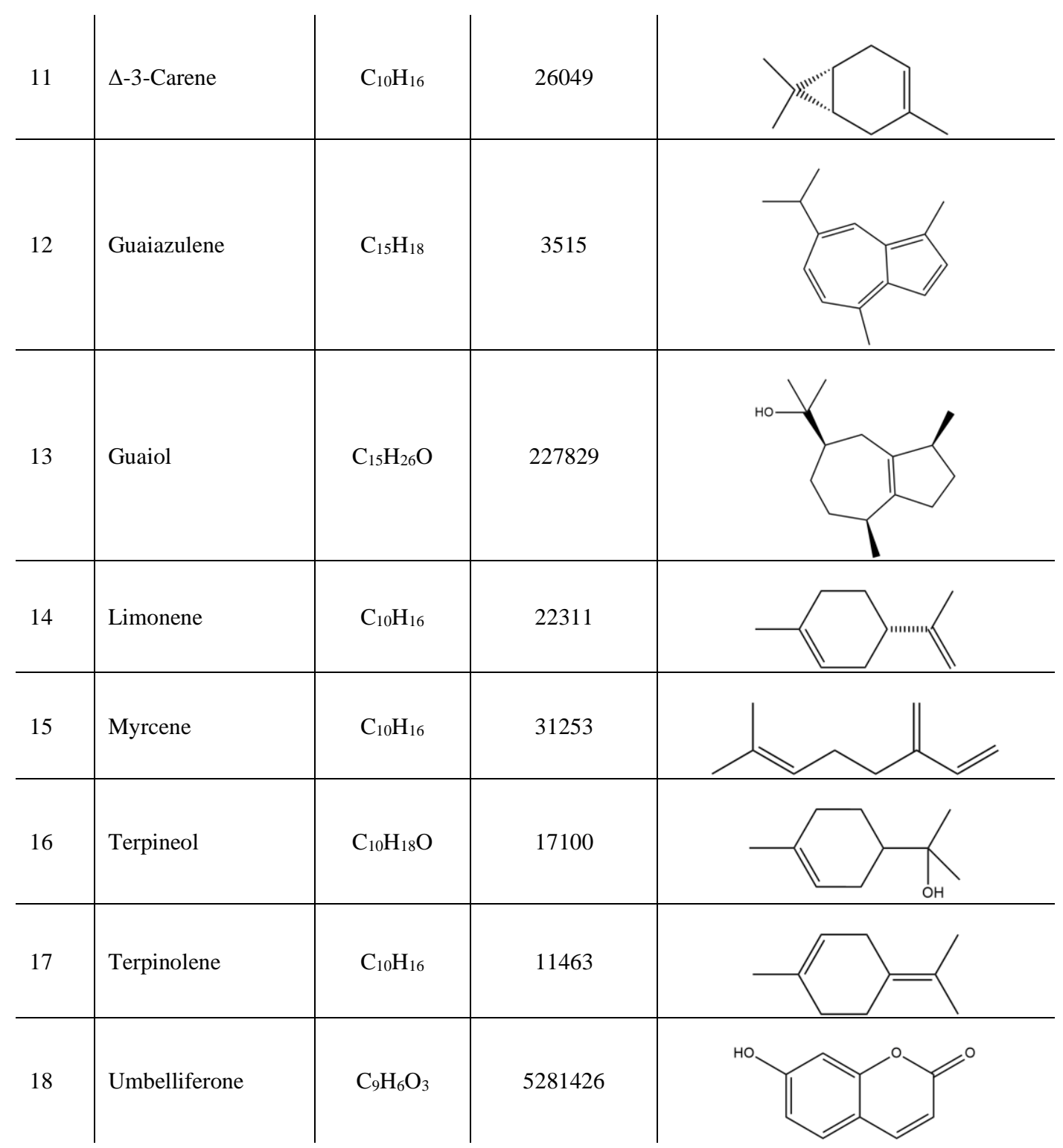

\subsection{Binding site prediction.}

The grid box parameters were calculated using AutoGrid tools of AutoDock 4.2. In each case, the grid maps of the receptors were obtained based on the position of co-crystal ligands bound to the proteins. Also, previous reports were considered in the selection of the docking pocket. After translating the ligand center to a defined area within the receptor active site, a grid box was built with a spacing of $0.375 \AA$ for each receptor. AutoDock Tools was applied to provide gpf and dpf files, including grid and docking parameters.

\subsection{Molecular docking.}

The docking simulations were carried out using the DOCKFACE program for the automatic performing of AutoDock 4.2. This application was designed to run the virtual ligand screening stepwise, including ligand preparation, receptor preparation, grid boxes generation, dpf files preparation, and finalization of docking runs [29,30]. The protein and ligand files were loaded as .pdbqt files for docking. These files were similar to .pdb files, including partial atomic charges $(\mathrm{q})$ and atom types $(\mathrm{t})$ for each ligand. The predicted binding pockets were selected, and the size of the 3-dimensional grid box was set to include the receptor's active site. The 
Lamarckian genetic algorithm (G.A.) method was applied to elucidate the collaboration design between the COVID-19 receptors and the active compounds of Ferula gummosa. The dockings were carried out on rigid receptors and flexible ligands. For Lamarckian GA, a gene mutation rate of 0.02, 27000 maximum generations, 2,500,000 maximum No. of energy evaluations, and 150 population size, a crossover rate of 0.8 , and 100 No. of G.A. run were applied. All calculations were run on a Core i7 computer (CPU at 8 M.B.). In all experiments, the best orientation of the ligand in the active site of the target receptor was determined. The lowest binding energy parameter was used to score the target-ligand association. To check the docking accuracy of the software, we have performed re-docking to the co-crystal bound ligand. All the docking simulations were validated with RMSD values below $2 \AA$.

\subsection{Molecular interaction analysis.}

All the interactions formed between the ligands and the receptors were visualized using the Autodock tools program (ADT, Version 1.5.6), PLIP (online protein-ligand interaction program) [31], and Discovery Studio Visualizer v.21.

The obtained poses from molecular docking were analyzed using Autodock tools. Out of several poses generated for each complex, the best pose having the least binding energy and high interactions was saved as a .pdb file for further evaluation. Various interactions such as hydrophobic and hydrogen bond interactions and the interaction distance between the ligands and amino acid residues were detected using PLIP. -Discovery Studio Visualizer v.21 was used to illustrate the 3-Dimensional representation of the complexes.

\subsection{Drug-likeness properties.}

Drug-likeness assesses qualitatively the chance for a molecule to become an oral drug concerning bioavailability [32]. Drug-likeness rules are a set of valuable principles applied to calculate the drug-like properties of the compounds. Using SwissADME (URL:https://www.swissadme.ch) [33], the ADME parameters, including drug-likeness, pharmacokinetics, and medicinal chemistry friendliness of the active compounds from Ferula gummosa, were investigated.

\section{Results and Discussion}

\subsection{Molecular docking results.}

The 18 active Ferula gummosa essential oil compounds were docked into the different receptors of SARS-CoV-2 (PDB IDs of 6LU7, 6XE1, 6W9C, 6M71). Different types of interactions, including hydrogen bonding, van der Waals, and other hydrophobic interactions, are exhibited in the docked complexes.

The 3CLpro receptor (PDB 6LU7) results include docking score energy (DS), between 18 compounds in Ferula gummosa and the receptor shown in Table 2. It is found that the best binding ability toward 6LU7 is in the sequence $\Delta$-Cadinene $>\gamma$-Cadinene $>\beta$-Eudesmol $>$ Guaiol $>$ Bulnesol $>\alpha$-cadinol $\approx$ Guaiazulene with lots of convergence points. $\Delta$-Cadinene and $\gamma$-Cadinene have shown the best inhibitory potentials with DS $=-6.77 \mathrm{kcal} / \mathrm{mol}, \mathrm{Ki}=10.92 \mu \mathrm{M}$ and $-6.74 \mathrm{kcal} / \mathrm{mol}, \mathrm{Ki}=11.40 \mu \mathrm{M}$, respectively. Visualizing the docked complex interactions showed that $\Delta$-Cadinene and $\gamma$-Cadinene shared hydrophobic interactions with the residues Glu166, Cys145, Met165, and Phe140. Cys145, which is usually vital in transferases [34-36], 
was observed to interact with $\Delta$-Cadinene and $\gamma$-Cadinene, and also forms a hydrogen bond with Bulnesol. Besides, the participation of Glu residues in these interactions is noteworthy since they are generally functionally important in isomerases [37]. Docking simulations of the interactions between $\Delta$-Cadinene and the 6LU7 receptor are presented in Figure 1a.

Table 2. Docking results of the active compounds of Ferula gummosa with 6LU7 (SARS-CoV-2) receptor.

\begin{tabular}{|c|c|c|c|c|}
\hline Compound & $\begin{array}{l}\text { Docking score } \\
\text { (Kcal/mol) }\end{array}$ & $\begin{array}{l}\text { No. of } \mathrm{H}- \\
\text { bonds }\end{array}$ & $\begin{array}{l}\text { Estimated inhibition } \\
\text { constant, } \mathrm{Ki}(\mu \mathrm{M})\end{array}$ & $\begin{array}{l}\text { Amino acid residues forming } H \text {-bond } \\
\text { with their length in } \AA\end{array}$ \\
\hline$\alpha$-Cadinol & -6.39 & 1 & 20.56 & Gln189 (A) H-donor \\
\hline$\alpha$-Pinene & -5.80 & $\ldots$ & 56.24 & $\ddot{\theta}$ \\
\hline$\beta$-Eudesmol & -6.66 & 2 & 13.15 & $\begin{array}{lll}\text { Met49 } & \text { (A) H-donor } & \text { (3.06) Gln189 } \\
& \text { (A) H-donor } & (2.83)\end{array}$ \\
\hline$\beta$-Pinene & -5.83 & $\ldots$ & 53.24 & \\
\hline Borneol & -5.58 & 1 & 80.63 & Gln189 (A) H-donor \\
\hline Bulnesol & -6.54 & 2 & 16.01 & $\begin{array}{lll}\text { His164 } & \text { (A) H-donor } & (2.72) \\
\text { Cys145 } & \text { (A) H-acceptor } & (3.60) \\
\end{array}$ \\
\hline Camphene & -5.91 & $\ldots$ & 46.87 & $\ldots$ \\
\hline cis-Osimene & -4.90 & $\ldots$ & 257.32 & $\ldots$ \\
\hline$\Delta$-Cadinene & -6.77 & $\ldots$ & 10.92 & $\ldots$ \\
\hline$\gamma$-Cadinene & -6.74 & $\ldots$ & 11.40 & $\ldots$ \\
\hline$\Delta$-3-Carene & -5.21 & $\ldots$ & 151.51 & $\ldots$ \\
\hline Guaiazulene & -6.39 & $\ldots$ & 20.70 & $\ldots$ \\
\hline Guaiol & -6.63 & 2 & 13.84 & $\begin{aligned} & \text { Phe140 (A) H-acceptor } \text { (2.84) His } \\
& 163 \text { (A) H-acceptor } \\
&(2.98)\end{aligned}$ \\
\hline Limonene & -5.45 & $\ldots$ & 101.24 & $\ldots$ \\
\hline Myrcene & -4.77 & $\ldots$ & 319.83 & \\
\hline Terpineol & -5.46 & 1 & 99.14 & Gln189 (A) H-donor \\
\hline Terpinolene & -5.17 & $\ldots$ & 162.61 & $\ldots$ \\
\hline Umbelliferone & -5.19 & 1 & 155.84 & His163 (A) H-acceptor (2.82) \\
\hline
\end{tabular}

The spike RBD protein (PDB 6XE1) is a possible druggable target due to its role in the viral attachment [38]. As can be seen from Table 3, the best docking scores for the bioactive compounds of Ferula gummosa with 6XE1 receptor are in the range of $\beta$-Eudesmol $>$ Bulnesol $>$ Guaiol $>$ Guaiazulene $>\alpha$-Cadinol $>\Delta$-Cadinene $>\gamma$-Cadinene. $\beta$-Eudesmol has shown the strongest inhibitory effect with $\mathrm{DS}=-6.70 \mathrm{kcal} / \mathrm{mol}$ and $\mathrm{Ki}=12.19 \mu \mathrm{M}$. It has formed two hydrogen bonds with Tyr369 (2.67 $\AA$ ) and Asn370 (3.24 $\AA$ ) residues of the E chain and hydrophobic interactions with residues Tyr369, Phe374, and Phe377. Bulnesol has shown DS $=-6.57 \mathrm{kcal} / \mathrm{mol}$ and $\mathrm{Ki}=15.17 \mu \mathrm{M}$. It has been observed to form 2 hydrogen bonds with Cys336 (2.54 $\AA$ ) and Gly339 (2.95 $\AA$ ) residues of the E chain and shared hydrophobic interactions with residues Ala363, Phe338, Leu335, and Leu368. The interactions observed for $\beta$-Eudesmol are represented in Figure 1b.

Table 3. Docking results of the active compounds of Ferula gummosa with 6XE1 (SARS-CoV-2) receptor.

\begin{tabular}{|c|c|c|c|c|}
\hline Compound & $\begin{array}{l}\text { Docking } \\
\text { score } \\
\text { (Kcal/mol) }\end{array}$ & $\begin{array}{l}\text { No. of H- } \\
\text { bonds }\end{array}$ & $\begin{array}{c}\text { Estimated } \\
\text { inhibition } \\
\text { constant, Ki }(\mu \mathrm{M})\end{array}$ & $\begin{array}{l}\text { Amino acid residues forming } \mathrm{H} \text { - } \\
\text { bond with their length in } \AA\end{array}$ \\
\hline$\alpha$-Cadinol & -6.41 & 1 & 19.95 & Cys336 (E) H-acceptor (2.73) \\
\hline$\alpha$-Pinene & -5.18 & $\ldots$ & 159.28 & $\ldots$ \\
\hline$\beta$-Eudesmol & -6.70 & 2 & 12.19 & $\begin{array}{lll}\text { Tyr369 } & \text { (E) H-donor } & (2.67) \\
\text { Asn370 } & \text { (E) H-acceptor } & (3.24)\end{array}$ \\
\hline$\beta$-Pinene & -5.10 & $\ldots$ & 181.15 & $\ldots$ \\
\hline Borneol & -5.27 & 3 & 137.82 & $\begin{array}{lll}\text { Cys336 (E) H-donor } & (2.96) \\
\text { Cys336 (E) H-acceptor } & (3.17) \\
\text { Ala363 (E) H-acceptor } & (3.30)\end{array}$ \\
\hline Bulnesol & -6.57 & 2 & 15.17 & $\begin{array}{l}\text { Cys336 (E) H-donor } \\
\text { Gly339 (E) H-donor }\end{array}$ \\
\hline Camphene & -5.17 & $\ldots$ & 161.05 & $\ldots$ \\
\hline cis-Osimene & -4.78 & $\ldots$ & 315.89 & $\ldots$ \\
\hline$\Delta$-Cadinene & -6.21 & $\ldots$ & 27.86 & $\ldots$ \\
\hline$\gamma$-Cadinene & -6.07 & $\ldots$ & 35.41 & $\cdots$ \\
\hline
\end{tabular}




\begin{tabular}{|c|c|c|c|c|}
\hline Compound & $\begin{array}{c}\text { Docking } \\
\text { score } \\
\text { (Kcal/mol) }\end{array}$ & $\begin{array}{l}\text { No. of H- } \\
\text { bonds }\end{array}$ & $\begin{array}{c}\text { Estimated } \\
\text { inhibition } \\
\text { constant, } \mathrm{Ki}(\boldsymbol{\mu M})\end{array}$ & $\begin{array}{l}\text { Amino acid residues forming } \mathrm{H} \text { - } \\
\text { bond with their length in } \AA\end{array}$ \\
\hline$\Delta$-3-Carene & -4.67 & $\ldots$ & 378.80 & $\ldots$. \\
\hline Guaiazulene & -6.42 & $\ldots$ & 19.70 & $\ldots$ \\
\hline Guaiol & -6.46 & 2 & 18.52 & $\begin{array}{l}\text { Cys336 (E) H-donor } \\
\text { Gly339 (E) H-acceptor }\end{array}$ \\
\hline Limonene & -4.85 & $\ldots$ & 279.71 & $\ldots$ \\
\hline Myrcene & -4.54 & $\ldots$ & 467.65 & \\
\hline Terpineol & -5.20 & 1 & 154.58 & Cys336 (E) H-donor \\
\hline Terpinolene & -5.15 & $\ldots$ & 169.02 & \\
\hline Umbelliferone & -5.19 & 1 & 155.64 & Cys336 (E) H-donor \\
\hline
\end{tabular}

Docking results of the interactions between different components of Ferula gummosa with PLpro receptor (PDB 6W9C) are presented in Table 4. The interaction order is listed as follows: $\Delta$-Cadinene $>\beta$-Eudesmol $>$ Guaiol $>\gamma$-Cadinene $>$ Guaiazulene $>$ Bulnesol. $\Delta$ Cadinene showed a docking score of $-6.91 \mathrm{kcal} / \mathrm{mol}$ and inhibition constant of $8.60 \mu \mathrm{M}$. Several amino acid residues were observed to form hydrophobic interactions with $\Delta$-Cadinene, such as Asn146, Ala135, Leu150, Ala131, Tyr71, Tyr72, Arg138, Ile14, and Asn13. $\beta$-Eudesmol showed a docking score of $-6.70 \mathrm{kcal} / \mathrm{mol}$ and inhibition constant of $12.37 \mu \mathrm{M}$. $\beta$-Eudesmol shared hydrophobic interactions with the residues Asp164, Arg166, Pro248, Tyr264. Along with that, it interacted with the binding residues Asp164 (2.91, 3.11) and Arg166 (3.07) via three hydrogen bonds. Docking simulations of the interactions between $\Delta$-Cadinene and 6W9C protein are represented in Figure 1c.

The anti-SARS-CoV-2 activity of the Ferula gummosa essential oil composition into the RdRp protein (PDB 6M71) has been found in the following order: $\Delta$-Cadinene > Guaiazulene $>$ Bulnesol $>\beta$-Eudesmol $>$ Guaiol $>$ Terpinolene $>\gamma$-Cadinene (Table 5). The compounds $\Delta$-Cadinene and Guaiazulene indicated the best docking scores of -7.65 and -7.09 , respectively. Several residues were involved in hydrophobic interactions with $\Delta$-Cadinene in the active pocket of the receptor (Figure 1d), including Arg349, Glu350, Thr319, Asn628, Asn459, Pro677, Val315, and Pro461. This compound has the highest binding affinity and the best inhibition constant $(\mathrm{Ki}=2.47 \mu \mathrm{M})$ among all results.

Table 4. Docking results of the active compounds of Ferula gummosa with 6W9C (SARS-CoV-2) receptor.

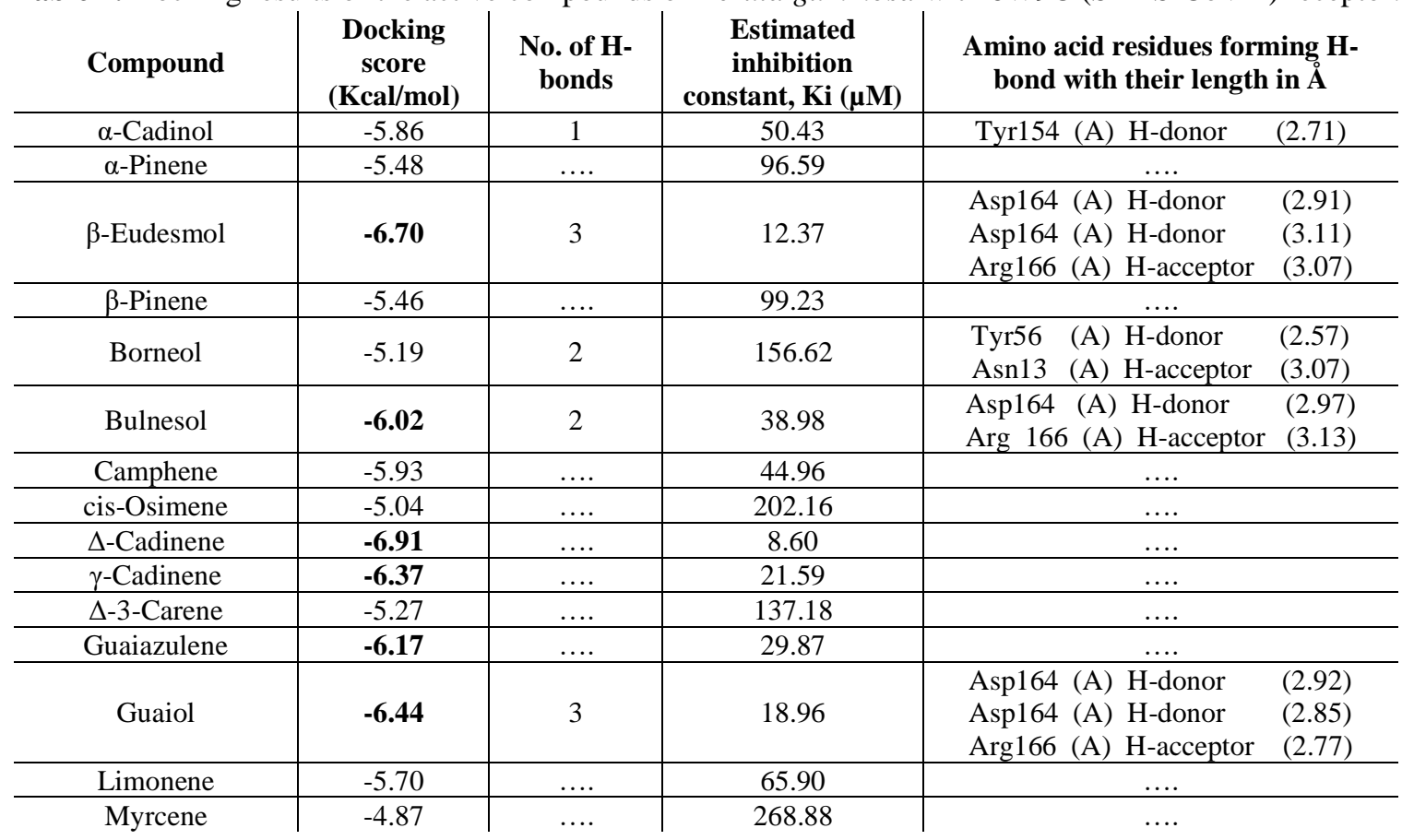




\begin{tabular}{|c|c|c|c|c|}
\hline Compound & $\begin{array}{l}\text { Docking } \\
\text { score } \\
\text { (Kcal/mol) }\end{array}$ & $\begin{array}{l}\text { No. of } \mathrm{H}- \\
\text { bonds }\end{array}$ & $\begin{array}{c}\text { Estimated } \\
\text { inhibition } \\
\text { constant, } \mathrm{Ki}(\mu \mathrm{M})\end{array}$ & $\begin{array}{l}\text { Amino acid residues forming } \mathrm{H} \text { - } \\
\text { bond with their length in } \AA\end{array}$ \\
\hline Terpineol & -5.83 & 2 & 53.38 & $\begin{array}{lll}\text { Asn146 (A) H-donor } & (2.84) \\
\text { Ala135 } & \text { (A) H-acceptor } & (3.59) \\
\end{array}$ \\
\hline Terpinolene & -5.98 & $\ldots$ & 41.04 & $\ldots$ \\
\hline Umbelliferone & -5.76 & 1 & 60.20 & $\begin{array}{lll}\text { Ala135 (A) H-acceptor } & (2.88) \\
\text { Tyr71 } & \text { (A) pi-H } & (3.66)\end{array}$ \\
\hline
\end{tabular}

Table 5. Docking results of the active compounds of Ferula gummosa with 6M71 (SARS-CoV-2) receptor.

\begin{tabular}{|c|c|c|c|c|}
\hline Compound & $\begin{array}{l}\text { Docking } \\
\text { score } \\
\text { (Kcal/mol) }\end{array}$ & $\begin{array}{l}\text { No. of } \mathrm{H}- \\
\text { bonds }\end{array}$ & $\begin{array}{c}\text { Estimated } \\
\text { inhibition constant, } \\
\mathbf{K i}(\mu \mathrm{M})\end{array}$ & $\begin{array}{l}\text { Amino acid residues forming } \mathrm{H} \text {-bond } \\
\text { with their length in } \AA\end{array}$ \\
\hline$\alpha$-Cadinol & -5.82 & 2 & 54.35 & $\begin{array}{ll}\text { Thr394 (A) H-donor } & (2.99) \\
\text { Cys395 (A) H-acceptor } & (3.90)\end{array}$ \\
\hline$\alpha$-Pinene & -5.35 & $\ldots$ & 120.09 & $\ldots$ \\
\hline$\beta$-Eudesmol & -6.50 & 3 & 17.15 & $\begin{array}{lll}\text { Asn459 (A) H-donor } & (2.54) \\
\text { Leu460 (A) H-acceptor } & (2.95) \\
\text { Pro461 (A) H-acceptor } & (2.78)\end{array}$ \\
\hline$\beta$-Pinene & -5.30 & & 129.74 & \\
\hline Borneol & -4.99 & 2 & 221.12 & $\begin{array}{lll}\text { Asp623 (A) H-donor } & (2.64) \\
\text { Lys621 (A) H-acceptor } & (2.97)\end{array}$ \\
\hline Bulnesol & -6.55 & 2 & 15.92 & $\begin{array}{lll}\text { Asp623 } & \text { (A) H-donor } & (2.71) \\
\text { Lys621 } & \text { (A) H-acceptor } & (2.96)\end{array}$ \\
\hline Camphene & -5.42 & $\ldots$ & 106.37 & $\ldots$ \\
\hline cis-Osimene & -5.84 & $\ldots$ & 52.14 & $\ldots$ \\
\hline$\Delta$-Cadinene & -7.65 & $\ldots$ & 2.47 & $\ldots$ \\
\hline$\gamma$-Cadinene & -6.03 & $\ldots$ & 37.75 & $\ldots$ \\
\hline$\Delta$-3-Carene & -5.13 & $\ldots$ & 174.64 & $\ldots$ \\
\hline Guaiazulene & -7.09 & $\ldots$ & 6.35 & $\ldots$ \\
\hline Guaiol & -6.28 & 2 & 25.03 & $\begin{array}{lll}\text { Asp623 (A) H-donor } & (2.61) \\
\text { Lys621 (A) H-acceptor } & (2.68) \\
\end{array}$ \\
\hline Limonene & -5.71 & $\ldots$ & 65.58 & $\ldots$ \\
\hline Myrcene & -5.27 & $\ldots$ & 138.25 & \\
\hline Terpineol & -5.40 & 2 & 110.94 & $\begin{array}{lll}\text { Glu350 (A) H-donor } & (2.70) \\
\text { Arg349 (A) H-acceptor } & (3.06)\end{array}$ \\
\hline Terpinolene & -6.04 & $\ldots$ & 37.51 & $\ldots$ \\
\hline Umbelliferone & -5.82 & 3 & 53.83 & $\begin{array}{lll}\text { Pro677 (A) H-donor } & (2.97) \\
\text { Thr462 (A) H-acceptor } & (2.93) \\
\text { Met629 (A) H-acceptor } & (3.67) \\
\text { Asn628 (A) pi-H } & (3.79)\end{array}$ \\
\hline
\end{tabular}
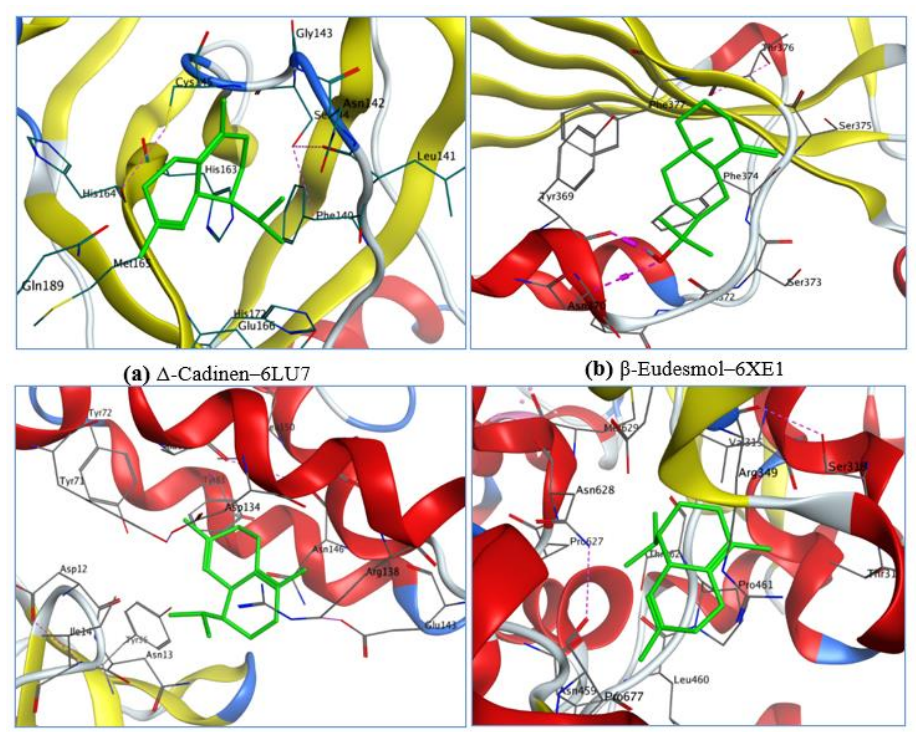

(c) $\Delta$-Cadinen-6W9C

(d) $\Delta$-Cadinen-6M71

Figure 1. 3-D representation of the best-screened ligand among the bioactive compounds of Ferula gummosa showing maximum docking scores against the druggable targets of SARS-CoV-2 (a) $\Delta$-Cadinen with 6LU7 receptor; (b) $\beta$-Eudesmol with 6 XE1 receptor; (c) $\Delta$-Cadinen with 6 W9C receptor ; (d) $\Delta$-Cadinen with $6 \mathrm{M} 71$ receptor. 


\subsection{Drug-likeness analysis.}

ADME parameters are calculated based on Lipinski's rule. As it has listed in Table 6, drug-likeness descriptors including Molecular Weight (M.W.) number of H-bond Donor (HBD), number of H-Bond Acceptor (HBA, Total Polar Surface Area (TPSA), Molar Refractivity (M.R.), Lipophilicity $(\log$ P), Water Solubility $(\log$ S) and G.I. absorption for all of the ligands were calculated.

Table 6. Drug-likeness descriptors of Ferula gummosa bioactive compounds, calculated by ADME software.

\begin{tabular}{c|c|c|c|c|c|c|c|c} 
Compound & M.W.(g/mol) & HBA & HBD & TPSA $\left.\mathbf{( A}^{\mathbf{0 2}}\right)$ & M.A. & Log P & Log S & $\begin{array}{c}\text { G.I. } \\
\text { absorption }\end{array}$ \\
\hline$\alpha$-Cadinol & 222.37 & 1 & 1 & 20.23 & 70.72 & 3.15 & -3.26 & High \\
\hline$\alpha$-Pinene & 136.23 & 0 & 0 & 0 & 45.22 & 2.63 & -3.51 & Low \\
\hline$\beta$-Eudesmol & 222.37 & 1 & 1 & 20.23 & 70.46 & 3.07 & -3.51 & High \\
\hline$\beta$-Pinene & 136.23 & 0 & 0 & 0 & 45.22 & 2.59 & -3.31 & Low \\
\hline Borneol & 154.25 & 1 & 1 & 20.23 & 46.60 & 2.44 & -2.51 & High \\
\hline Bulnesol & 222.37 & 1 & 1 & 20.23 & 70.72 & 3.20 & -2.99 & High \\
\hline Camphene & 136.23 & 0 & 0 & 0 & 45.22 & 2.58 & -3.34 & Low \\
\hline cis-Osimene & 136.23 & 0 & 0 & 0 & 48.76 & 2.80 & -3.17 & Low \\
\hline$\Delta$-Cadinene & 204.35 & 0 & 0 & 0 & 69.04 & 3.41 & -3.43 & Low \\
\hline$\gamma$-Cadinene & 204.35 & 0 & 0 & 0 & 69.04 & 3.39 & -3.76 & Low \\
\hline$\Delta-3$-Carene & 136.23 & 0 & 0 & 0 & 45.22 & 2.63 & -3.44 & Low \\
\hline Guaiazulene & 198.3 & 0 & 0 & 0 & 67.58 & 3.11 & -4.50 & Low \\
\hline Guaiol & 222.37 & 1 & 1 & 20.23 & 70.72 & 3.08 & -3.09 & High \\
\hline Limonene & 136.23 & 0 & 0 & 0 & 47.12 & 2.72 & -3.50 & Low \\
\hline Myrcene & 136.23 & 0 & 0 & 0 & 48.76 & 2.89 & -3.05 & Low \\
\hline Terpineol & 154.25 & 1 & 1 & 20.23 & 48.80 & 2.51 & -2.87 & High \\
\hline Terpinolene & 136.23 & 0 & 0 & 0 & 47.12 & 2.71 & -3.50 & Low \\
\hline Umbelliferone & 162.14 & 3 & 1 & 50.44 & 44.51 & 1.44 & -2.46 & High
\end{tabular}

M.W.:Molecular Weight, HBA: number of H-bond Acceptor, HBD: number of H-bond Donor, TPSA: Total Polar Surface Area, M.R.: Molar Refractivity, $\log$ P: Lipophilicity, $\log$ S: Water Solubility.

\section{Conclusions}

The present study has been focused on the application of herbal medicine in the treatment of COVID-19. Ferula gummosa, as a valuable medicinal plant of Iran, possesses various biological and medical activities for its numerous terpenoid compounds. These natural phytochemical compounds, which have anti-inflammatory or antiviral properties, have been selected to tackle the current pandemic SARS-CoV-2 using in-silico evaluation. A molecular docking simulation was performed, and the results showed that at least ten bioactive substances of Ferula gummosa essential oil are capable of inhibiting the possible active binding sites of SARS-CoV-2. The three components $\Delta$-Cadinene, $\beta$-Eudesmol, and Bulnesol, had the best docking scores and can be considered substantial inhibitors for 6LU7, 6XE1, 6W9C, and 6M71 receptors of SARS-CoV-2. This research can provide a lead in analyzing the antiviral activity of these compounds to prevent and limit the infection of SARS-CoV-2.

\section{Funding}

This research received no external funding.

\section{Acknowledgments}

The authors wish to express their appreciation to Dr. Masood Fereidoonnezhad (Ahvaz Jundishapur University of Medical Sciences) for his kind guidance and valuable comments during the design and conduction of this investigation. 


\section{Conflicts of Interest}

The authors declare no conflict of interest.

\section{References}

1. General's Opening Remarks at the Media Briefing on COVID-19-11 March 2020 of Site. Available online: https://www.who.int/director-general/speeches/detail/who-director-general-s-opening-remarks-at-themedia-briefing-on-covid-19---11-march-2020 (accessed on 27 April 2021).

2. Ludwig, S.; Zarbock, A. Coronaviruses and SARS-CoV-2: A Brief Overview. Anesthesia \& Analgesia 2020, 131, 93-96, https://doi.org/10.1213/ANE.0000000000004845.

3. COVID-19 CORONAVIRUS PANDEMIC of Site. Available online: https://www.worldometers.info/coronavirus/ (accessed on 7 March 2021).

4. Mhatre, S.; Srivastava, T.; Naik, S.; Patravale, V. Antiviral activity of green tea and black tea polyphenols in prophylaxis and treatment of COVID-19: A review. Phytomedicine 2021, 85, https://doi.org/10.1016/j.phymed.2020.153286.

5. Wu, C.; Liu, Y.; Yang, Y.; Zhang, P.; Zhong, W.; Wang, Y.; Wang, Q.; Xu, Y.; Li, M.; Li, X.; Zheng, M.; Chen, L.; Li, H. Analysis of therapeutic targets for SARS-CoV-2 and discovery of potential drugs by computational methods. Acta Pharmaceutica Sinica B 2020, 10, 766-788, https://doi.org/10.1016/j.apsb.2020.02.008.

6. Mhatre, S.; Naik, S.; Patravale, V. A molecular docking study of EGCG and theaflavin digallate with the druggable targets of SARS-CoV-2. Computers in Biology and Medicine 2021, 129, https://doi.org/10.1016/j.compbiomed.2020.104137.

7. Prajapat, M.; Sarma, P.; Shekhar, N.; Avti, P.; Sinha, S.; Kaur, H.; Kumar, S.; Bhattacharyya, A.; Kumar, H; Bansal, S. Drug targets for corona virus: A systematic review. Indian journal of pharmacology 2020, 52.

8. Borgio, J.F.; Alsuwat, H.S.; Al Otaibi, W.M.; Ibrahim, A.M.; Almandil, N.B.; Al Asoom, L.I.; Salahuddin, M.; Kamaraj, B.; AbdulAzeez, S. State-of-the-art tools unveil potent drug targets amongst clinically approved drugs to inhibit helicase in SARS-CoV-2. Archives of medical science: AMS 2020, 16, https://doi.org/10.5114/aoms.2020.94567.

9. Azeez, S.A.; Alhashim, Z.G.; Al Otaibi, W.M.; Alsuwat, H.S.; Ibrahim, A.M.; Almandil, N.B.; Borgio, J.F. State-of-the-art tools to identify druggable protein ligand of SARS-CoV-2. Archives of medical science: AMS 2020, 16, https://doi.org/10.5114/aoms.2020.94046.

10. da Silva, J.K.R.; Figueiredo, P.L.; Byler, K.G.; Setzer, W.N. Essential Oils as Antiviral Agents, Potential of Essential Oils to Treat SARS-CoV-2 Infection: An In-Silico Investigation. International Journal of Molecular Sciences 2020, 21, https://doi.org/10.3390/ijms21103426.

11. Asif, M.; Saleem, M.; Saadullah, M.; Yaseen, H.S.; Al Zarzour, R. COVID-19 and therapy with essential oils having antiviral, anti-inflammatory, and immunomodulatory properties. Inflammopharmacology 2020, 28, 1153-1161, https://doi.org/10.1007/s10787-020-00744-0.

12. Ang, L.; Lee, H.W.; Kim, A.; Lee, M.S. Herbal medicine for the management of COVID-19 during the medical observation period: a review of guidelines. Integrative Medicine Research 2020, 9, https://doi.org/10.1016/j.imr.2020.100465.

13. Mahboubi, M. Ferula gummosa, a Traditional Medicine with Novel Applications. Journal of Dietary Supplements 2016, 13, 700-718, https://doi.org/10.3109/19390211.2016.1157715.

14. Ferula gummosa Boiss of $\quad$ Site. Available https://pfaf.org/user/Plant.aspx?LatinName=Ferula+gummosa (accessed on 7 March 2021).

15. Khare, C.P. Ferula galbaniflua Boiss. ex Buhse of the chapter. In: Indian Medicinal Plants: An Illustrated Dictionary. 2nd ed.; Khare, CP. Khare, CP. Eds.; Springer New York: Springer New York Location, Volume 3, Country, 2007; pp. 1-1.

16. Zargaran, A.; Mehdizadeh, A.; Zarshenas, M.M.; Mohagheghzadeh, A. Avicenna (980-1037 AD). Journal of Neurology 2012, 259, 389-390, https://doi.org/10.1007/s00415-011-6219-2.

17. Boghrati, Z.; Iranshahi, M. Ferula species: A rich source of antimicrobial compounds. Journal of Herbal Medicine 2019, 16, https://doi.org/10.1016/j.hermed.2018.10.009.

18. Nabavi, S.F.; Habtemariam, S.; Sureda, A.; Nabavi, S.M. Ferula gummosa boiss as a rich source of natural antioxidants with numerous therapeutic uses-a short review of the chapter. In: Medicinal Plants as Antioxidant Agents: Understanding Their Mechanism of Action and Therapeutic Efficacy. 2nd ed.; Capasso, A. Capasso, A. Eds.; Location, Country, Volume 3, 2012; pp. 15-26.

19. Najafabadi, A.S.; Naghavi, M.R.; Farahmand, H.; Abbasi, A.; Yazdanfar, N. Chemical Composition of the Essential Oil from Oleo-gum-resin and Different Organs of Ferula gummosa. Journal of Essential Oil Bearing Plants 2017, 20, 282-288, https://doi.org/10.1080/0972060X.2016.1263582.

20. Askari, V.R.; Alavinezhad, A.; Rahimi, V.B.; Rezaee, S.A.; Boskabady, M.H. Immuno-modulatory effects of methanolic extract of Ferula szowitsiana on isolated human Th1/Th2/Treg cytokines levels, and their genes expression and nitric oxide production. Cytokine 2021, 138, https://doi.org/10.1016/j.cyto.2020.155387. 
21. Jain, A.S.; Sushma, P.; Dharmashekar, C.; Beelagi, M.S.; Prasad, S.K.; Shivamallu, C.; Prasad, A.; Syed, A.; Marraiki, N.; Prasad, K.S. In silico evaluation of flavonoids as effective antiviral agents on the spike glycoprotein of SARS-CoV-2. Saudi Journal of Biological Sciences 2021, 28, 1040-1051, https://doi.org/10.1016/j.sjbs.2020.11.049.

22. Kulkarni, S.A.; Nagarajan, S.K.; Ramesh, V.; Palaniyandi, V.; Selvam, S.P.; Madhavan, T. Computational evaluation of major components from plant essential oils as potent inhibitors of SARS-CoV-2 spike protein. Journal of Molecular Structure 2020, 1221, https://doi.org/10.1016/j.molstruc.2020.128823.

23. Thuy, B.T.P.; My, T.T.A.; Hai, N.T.T.; Hieu, L.T.; Hoa, T.T.; Thi Phuong Loan, H.; Triet, N.T.; Anh, T.T.V.; Quy, P.T.; Tat, P.V.; Hue, N.V.; Quang, D.T.; Trung, N.T.; Tung, V.T.; Huynh, L.K.; Nhung, N.T.A. Investigation into SARS-CoV-2 Resistance of Compounds in Garlic Essential Oil. ACS Omega 2020, 5, 83128320, https://doi.org/10.1021/acsomega.0c00772.

24. My, T.T.A.; Loan, H.T.P.; Hai, N.T.T.; Hieu, L.T.; Hoa, T.T.; Thuy, B.T.P.; Quang, D.T.; Triet, N.T.; Anh, T.T.V.; Dieu, N.T.X.; Trung, N.T.; Hue, N.V.; Tat, P.V.; Tung, V.T.; Nhung, N.T.A. Evaluation of the Inhibitory Activities of COVID-19 of Melaleuca cajuputi Oil Using Docking Simulation. ChemistrySelect 2020, 5, 6312-6320, https://doi.org/10.1002/slct.202000822.

25. Karakaya, S.; Göger, G.; Bostanlik, F.D.; Demirci, B.; Duman, H.; Kiliç. C.S. Comparison of the Essential Oils of Ferula orientalis L., Ferulago sandrasica Peşmen and Quézel, and Hippomarathrum microcarpum Petrov and Their Antimicrobial Activity. Turk J Pharm Sci 2019, 16, 69-75, https://doi: 10.4274/tjps.77200.

26. Gasteiger, J.; Marsili, M. Iterative partial equalization of orbital electronegativity - a rapid access to atomic charges. Tetrahedron 1980, 36, 3219-3228, https://doi.org/10.1016/0040-4020(80)80168-2.

27. Morris, G.M.; Huey, R.; Olson, A.J. Using AutoDock for Ligand-Receptor Docking. Current Protocols in Bioinformatics 2008, 24, 8.14.11-18.14.40, https://doi.org/10.1002/0471250953.bi0814s24.

28. Weiner, S.J.; Kollman, P.A.; Case, D.A.; Singh, U.C.; Ghio, C.; Alagona, G.; Profeta, S.; Weiner, P. A new force field for molecular mechanical simulation of nucleic acids and proteins. Journal of the American Chemical Society 1984, 106, 765-784, https://doi.org/10.1021/ja00315a051.

29. Mojaddami, A.; Sakhteman, A.; Fereidoonnezhad, M.; Faghih, Z.; Najdian, A.; Khabnadideh, S.; Sadeghpour, H.; Rezaei, Z. Binding mode of triazole derivatives as aromatase inhibitors based on docking, protein ligand interaction fingerprinting, and molecular dynamics simulation studies. 2017, 12, 21-30, https://doi.org/10.4103/1735-5362.199043.

30. Zare, S.; Fereidoonnezhad, M.; Afshar, D.; Ramezani, Z. A comparative QSAR analysis and molecular docking studies of phenyl piperidine derivatives as potent dual NK1R antagonists/serotonin transporter (SERT) inhibitors. Computational Biology and Chemistry 2017, 67, 22-37, https://doi.org/10.1016/j.compbiolchem.2016.12.004.

31. Salentin, S.; Schreiber, S.; Haupt, V.J.; Adasme, M.F.; Schroeder, M. PLIP: fully automated protein-ligand interaction profiler. Nucleic acids research 2015, 43, W443-W447, https://doi.org/10.1093/nar/gkv315.

32. Daina, A.; Michielin, O.; Zoete, V. SwissADME: a free web tool to evaluate pharmacokinetics, drug-likeness and medicinal chemistry friendliness of small molecules. Scientific Reports 2017, 7, https://doi.org/10.1038/srep42717.

33. Tsaioun, K.; Blaauboer, B.J.; Hartung, T. Evidence-based absorption, distribution, metabolism, excretion (ADME) and its interplay with alternative toxicity methods. Alternatives to Animal Experimentation: ALTEX 2016, 33, 343-358, https://dx.doi.org/10.14573/altex.1610101.

34. Mahanta, S.; Chowdhury, P.; Gogoi, N.; Goswami, N.; Borah, D.; Kumar, R.; Chetia, D.; Borah, P.; Buragohain, A.K.; Gogoi, B. Potential antiviral activity of approved repurposed drug against main protease of SARS-CoV-2: an in silico based approach. Journal of Biomolecular Structure and Dynamics 2021, 39, 3802-3811, https://doi.org/10.1080/07391102.2020.1768902.

35. Chenot, C.; Robiette, R.; Collin, S. First Evidence of the Cysteine and Glutathione Conjugates of 3Sulfanylpentan-1-ol in Hop (Humulus lupulus L.). Journal of Agricultural and Food Chemistry 2019, 67, 4002-4010, https://doi.org/10.1021/acs.jafc.9b00225.

36. Elmezayen, A.D.; Al-Obaidi, A.; Şahin, A.T.; Yelekçi, K. Drug repurposing for coronavirus (COVID-19): in silico screening of known drugs against coronavirus 3CL hydrolase and protease enzymes. Journal of Biomolecular Structure and Dynamics 2021, 39, 2980-2992, https://doi.org/10.1080/07391102.2020.1758791.

37. Holliday, G.L.; Mitchell, J.B.O.; Thornton, J.M. Understanding the Functional Roles of Amino Acid Residues in Enzyme Catalysis. Journal of Molecular Biology 2009, 390, 560-577, https://doi.org/10.1016/j.jmb.2009.05.015.

38. Mhatre, S.; Naik, S.; Patravale, V. A molecular docking study of EGCG and theaflavin digallate with the druggable targets of SARS-CoV-2. Computers in Biology and Medicine 2021, 129, https://doi.org/10.1016/j.compbiomed.2020.104137. 